\title{
RECREATIONAL USES AND MOTIVATIONS OF VISITORS IN SEASIDE WETLANDS OF COSTA BRAVA (SPAIN)
}

\author{
JOSEP PUEYO-ROS, ANNA RIBAS \& ROSA M. FRAGUELL \\ Department of Geography, University of Girona, Spain.
}

\begin{abstract}
Seaside wetlands bring together a huge quantity of services and functions, especially ecological and social. All of them depend on the ecological quality of ecosystems and on the equipment and service that allow them to be enjoyed. Tourism is an economic segment, carrying an important weight in most coastal regions around the world. Hence a complete environmental management of seaside wetlands should include the touristic perspective. In this communication, we analyse usage and motivation in three seaside wetlands of the Costa Brava (Spain) through a survey realized in the months of the highest occurrence of visitors (from June to September 2015). From the results, we highlight the high number of visitors who use the sites for recreational purposes (49\%), such as running or cycling, in comparison with visitors who stated aesthetic motivations (16\%). Many visitors also stated no motivation for visiting the sites (31\%); they use them as car parks to go to the beach or as a byway to other sites. On the other hand, most visitors stressed the landscape (30\%) or the degree of naturalness (29\%) as a positive element of seaside wetlands, while the majority of negative elements are linked to bad management of the site $(36 \%)$. When we requested a landscape valuation in a five-point scale, a significant number of high values were shown. Furthermore, we found a link between evaluation and tourism typology (local, national or foreign, lodged or excursionist) and motivation for visit (recreational, aesthetic or without). The principal conclusion is that, despite the fact that the main uses of the seaside wetlands are recreational, tourists appreciate landscape quality and degree of naturalness in sites where they develop their activities. This assigns to tourism, especially seaside tourism, an active role in conservation of seaside wetlands.
\end{abstract}

Keywords: ecosystem services, landscape values, seaside wetlands, tourism, wetlands perception, wetlands uses.

\section{INTRODUCTION}

Seaside wetlands offer a huge variety of ecosystem services (ES) that contribute to human well-being. The most important are protection against weather events like floods or hurricanes, water and food provision and recreational uses by local inhabitants and tourism [1]. The perceived importance of each function depends on the social context where the wetlands are located. Polish research showed that local inhabitants prioritized protection against floods over recreational uses or higher biodiversity [2]. In Louisiana, on the other hand, historical context meant that the main benefit stated by local inhabitants was protection against hurricanes [3]. Despite provisioning services still being very important in developing countries [4], they are losing their prominence in industrialized countries in favour of recreational activities, such as walking, birdwatching or recreational fisheries $[2,5,6]$, to the extent that the value of recreation on the western Mediterranean coast is amongst the highest around the world [7].

This paper is part of the Proceedings of the $7^{\text {th }}$ International Conference on Sustainable Tourism (Sustainable Tourism 2016)

www.witconferences.com
} 
Despite the prominence of the ES that they provide, seaside wetlands are under strong pressure from human activities, becoming the most degraded ecosystems around the world [8]. A few years ago, wetlands were perceived as negative landscapes because of diseases like malaria. This perception started to change in the second half of the 20th century, when some studies showed that wetlands had higher aesthetic values than other landscapes thanks to the contact between land and water [9]. This perception changes, however, when referring to seaside wetlands like saltmarshes, because they do not fit into the canons of Romantic nature [10]. Degradation suffered by seaside wetlands caused a reduction in their aesthetic and recreational values. For instance, a decrease of surface produces a loss in perceived value [11, 12] or issues such as eutrophication produce a severe fall in recreational and aesthetic values [1]. Although Nassauer [10] considered that quality perceptions and ecological quality have little relationship, it is obvious that the ES that wetlands offer are directly linked to ecosystem health. Furthermore, a growing regard of visitors for biological diversity and abundance is being established [1].

The littoral of the western Mediterranean is an essentially touristic area; thus conservation projects in wetlands should consider the values and preferences of tourism as well as those of local inhabitants. Tourism is able to adopt a key role in wetlands conservation, as is stated in RAMSAR convention (Convention on Wetlands of International Importance, especially as Waterfowl Habitat) [13]. Several examples where tourists are involved in local environmental projects can be found $[14,15]$. Perceived ecosystem benefits are the reason because people want to promote conservation, to enjoy the services in the future. Most wetlands' functions have a high value because, if the wetlands disappeared, substitution costs would be very high [16], but the recreational function is the only one which can generate perceivable income by means of tourism, especially in industrialized countries where provisioning services are significant. Hence, tourism could facilitate local inhabitants perceiving wetlands as an economic resource which should be protected. Tourists visit wetlands for natural resources [17]. At the same time, strong competition is detected between wetlands to attract tourism [18]. That can help to convince local inhabitants to promote conservation policies in order to be more competitive in attracting tourism. Furthermore, a generalist tourist could become a nature-based tourist with nature-based experiences [19]; thus wetlands can also help to reduce the proportion of sun-and-beach tourism in western Mediterranean destinations - one of the main issues responsible for wetlands' degradation [20] - as well as reducing other unwanted issues like beach overcrowding or seasonality [21,22].

Because of the above-mentioned, we have focussed on the recreational and aesthetic functions of seaside wetlands, because they are the most influential in conservation attitudes and policies. Developing nature-based recreational activities promotes better environmental attitudes because it increases place attachment and conservation commitment [17]. Hence, improving recreational functions contributes to increased environmental attitudes in visitors. Understanding how people perceive and use ecosystem services is important because they determine visitors' behaviour [23]. Nevertheless, most previous studies focused on the economic values of wetland recreational uses [7, 24] and not on the nature of them. Different recreational uses (walking, running, wildlife-watching and so on) produce different kinds of place attachment [25]. Furthermore, it is not only recreational values that are important in improving visitors' behaviour, aesthetic values are also significant. Tourists who develop more passive or contemplative activities are more aware of nature than tourists who participate in more active activities [19], but most methods used to analyse recreational functions did not allow those aspects to be distinguished [26]. Thus, in this communication we analyse the evaluation of seaside wetlands by visitors and the recreational uses, preferences and motivations stated by visitors. 


\section{DESCRIPTION OF STUDY AREA}

The research was developed in the natural park Montgrí, Illes Medes I Baix Ter. It is located in the Costa Brava tourism destination (Spain), which focuses on sun-and-beach tourism [27]; beaches are the main touristic resource [22] and wetlands are not very relevant in the whole destination. It is a marine and inland protected area with low mountains and saltmarshes. It has an area of 8192 ha (2037 are marine). From park sites, three wetlands that were representative of all wetlands in the park were selected. All of these are wildlife refuges (category IV of International Union for Conservation of Nature (IUCN)) (Fig. 1), but the natural park council opted to promote mountain and maritime areas, they marginalized wetlands because they are dispersed and represent a small area [28]. Hence, the analysed wetlands are not huge wet expanses with prominence as can be found in similar regions like 'Doñana' or 'Delta de l'Ebre' in Spain or 'La Camargue' in France. The analysed wetlands are interstitial spaces in a landscape modified by mass tourism. That gives an added interest regarding conservation because if they did not receive attention, they would disappear under the urbanistic pressure caused by mass tourism.

The first of the selected wetlands is known as 'les Basses del Ter Vell', located in the old mouth of the river Ter. It is basically a compound of two permanent lagoons of $5000 \mathrm{~m}^{2}$ surrounded by an area of 18 ha of reed (Phragmites australis). It can only be visited from an elevated observation point in front of the main lagoon. The second wetland is 'La Pletera', a Salicornia expanse degraded by an urbanization process that was stopped. Nowadays only streets and a promenade remain. Vegetation is compounded by patches of Salicornia and patches of Mediterranean scrubs. It represents an area of 45 ha. The site includes a permanent lagoon and a few temporary ones. The last selected wetland is 'les Basses d'en Coll', which is a 3.5 ha lagoon surrounded by 41 ha of rice crops and reed. It includes several paths across the rice crops and to access the lagoon and an elevated observation point (see Fig. 2).

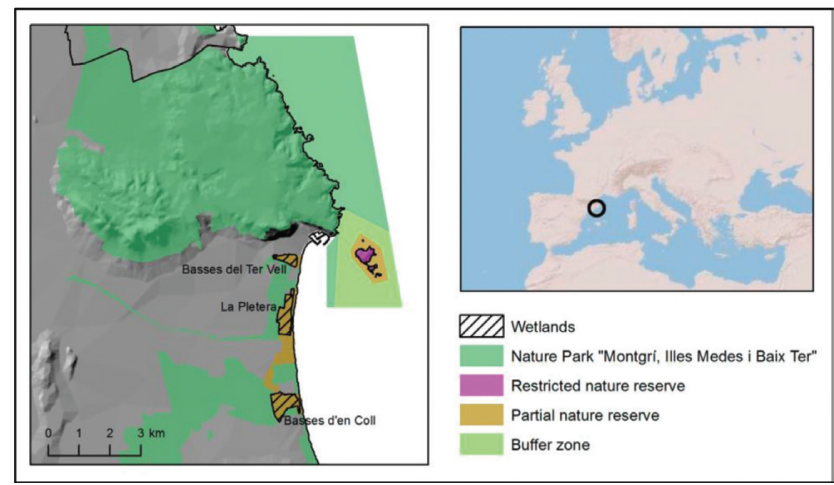

Figure 1: Map and location of Natural Park Montgrí, Illes Medes I Baix Ter.

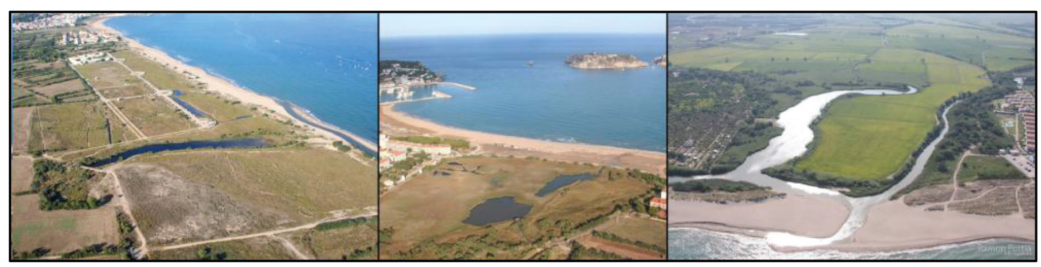

Figure 2: Aerial picture of three selected wetlands. From left to right: La Pletera, les Basses del Ter Vell and les Basses d'en Coll. 


\section{METHODS}

To analyse recreational uses of wetlands, we opted to combine survey collection with direct observation. Surveys included closed-ended and open-ended questions. The former concerned the sociodemographic characteristics of visitors and the latter the motivation for visiting the wetlands, the positive and negative elements of the visited site and visit frequency. An evaluation of the site on a five-point scale was also requested. Data collection took place from June to September 2015, the months with maximum tourist influx. Data was collected from Monday to Sunday and from 8:00 am to 9:00 pm in a proportional way to capture all kinds of visitors. During survey collection, survey takers also noted down the uses that visitors made of the sites (walking, running, cycling, going to the beach or horse riding). With those observations, we calculated the proportion of visitors engaged in the different wetlands uses. Those observations were not made in 'les Basses del Ter Vell', because the area is restricted and can only be visited from an observation point. It would cause a bias in the proportion of uses. To calculate the percentages of each use, the number of visitors was weighted with the inverse of observation hours at a site, to compensate for the difference in observation hours between both sites.

Once the surveys were collected, open-ended questions were submitted to a codification process to establish categories [29]. Coded answers were motivation for visit, visit frequency, positive elements and negative elements of wetland. The sample was also distinguished according to origin. Establishing three categories: local (from the municipalities of the natural park), national (from Spain) and foreign (from the rest of the world). Combining origin with overnight stay (main home, second home or touristic accommodation), we created six typologies of visitors (Table 1).

After codification, we looked for relationships between evaluation of the wetlands and the rest of the variables to know which elements influence the evaluations. Because that variable did not show a normal distribution, Kruskal-Wallis test was used [30]. Relationships with a confidence level of $\mathrm{p}<0.1$ were considered significant.

\section{RESULTS}

The number of completed surveys was 141 (Basses del Ter Vell: 41, La Pletera: 52, Basses d'en Coll: 48). A distinction was made according to time of collection: morning (before 12:00 am), noon (from 12:00 am to 4:00 pm) and afternoon (after 4:00 pm). Results were as follows: 71 surveys were collected in the mornings, 10 at noon and 60 in the afternoons. Few surveys were collected at noon because they are hours when the sites are little frequented due to the heat and the sun. Of 141 surveyed visitors, 47 stayed at their main home, 45 owned a second home and 49 were lodged in touristic accommodation. Regarding origin, 20 visitors came from local municipalities, 90 were national visitors and 31 were foreign. The combination of both categories is shown in Table 2 .

Table 1: Visitors' typologies according to origin and overnight stay.

\begin{tabular}{lll}
\hline Typology & Origin & Overnight Stay \\
\hline Local & Local & Main home \\
Excursionist & National, foreign & Main home \\
National tourist & National & Touristic accommodation \\
Foreign tourist & Foreign & Touristic accommodation \\
National second home & National & Second home \\
Foreign second home & Foreign & Second home \\
\hline
\end{tabular}


Direct observations noted down the wetland usage of 609 visitors. The most frequent use is cycling (42.55\%), while, in second place, is the use of the wetland as a car park to access the beach $(30.39 \%)$. Similar percentages of visitors used the wetlands to run or walk $(14.61 \%$ and $11.88 \%$, respectively). Finally, horse riding was a marginal use $(0.56 \%)$.

The results of codification are also shown in Table 2. Motivation for visiting the wetlands were classified in four categories: aesthetic, recreational, to search for tranquillity and visitors who stated having no motivation because they were visiting the site on the way to the beach or other areas in the park. Frequency was divided into high, medium and low, considering the frequency of visits and whether seasonal or permanent. Regarding positive and negative elements, both were summarized in six categories. Landscape and degree of naturalness were the most frequent positive elements. Issues related to bad management, such as dirty, uncared for signposts or equipment in bad condition, were mentioned by most visitors.

Table 2: Description of answers and codification.

\begin{tabular}{|c|c|c|c|c|}
\hline Variable & Category & Description & $\mathbf{n}$ & $\%$ \\
\hline \multirow{4}{*}{ Wetland } & Pletera & Visitors to 'la Pletera' wetland & 52 & 36.88 \\
\hline & Basses_Coll & Visitors to 'les Basses d'en Coll' wetland & 48 & 34.04 \\
\hline & Ter_Vell & Visitors to 'les Basses del Ter Vell' wetland & 41 & 29.08 \\
\hline & Morning & Visitors in the morning & 71 & 50.35 \\
\hline \multirow[t]{2}{*}{ Time } & Afternoon & Visitors in the afternoon & 60 & 42.55 \\
\hline & Noon & Visitors at noon & 10 & 7.09 \\
\hline \multirow{3}{*}{$\begin{array}{l}\text { Overnight } \\
\text { stay }\end{array}$} & Accommodation & Lodged in touristic accommodation & 49 & 34.75 \\
\hline & Main home & Visiting wetland from main home & 47 & 33.33 \\
\hline & Second home & He/she owns a second home & 45 & 31.91 \\
\hline \multirow{4}{*}{ Origin } & National & From Spain & 90 & 63.83 \\
\hline & Foreign & From outside Spain & 31 & 21.99 \\
\hline & Local & From municipalities of the Natural Park & 20 & 14.18 \\
\hline & National tourist & National visitors lodged in accommodation & 32 & 22.70 \\
\hline \multirow{5}{*}{ Typology } & $\begin{array}{l}\text { National second } \\
\text { home }\end{array}$ & National visitors who stay in a second home & 31 & 21.99 \\
\hline & Excursionist & $\begin{array}{l}\text { National or foreign visitors who come from } \\
\text { main home }\end{array}$ & 27 & 19.15 \\
\hline & Local inhabitant & From municipalities of the Natural Park & 20 & 14.18 \\
\hline & Foreign tourist & Foreign visitors lodged in accommodation & 17 & 12.06 \\
\hline & $\begin{array}{l}\text { Foreign second } \\
\text { home }\end{array}$ & Foreign visitors who stay in a second home & 14 & 9.93 \\
\hline \multirow{4}{*}{ Motivation } & Recreational & Walking, running or cycling & 69 & 48.94 \\
\hline & $\begin{array}{l}\text { Without } \\
\text { motivation }\end{array}$ & $\begin{array}{l}\text { Visitors who use the wetland as a car park to } \\
\text { access the beach or as a byway to other areas }\end{array}$ & 43 & 30.50 \\
\hline & Aesthetic & $\begin{array}{l}\text { Enjoy landscape or particular elements like } \\
\text { wildlife or lagoons }\end{array}$ & 23 & 16.31 \\
\hline & Tranquillity & Main motivation is searching for tranquillity & $\begin{array}{l}6 \\
(C\end{array}$ & $\begin{array}{c}4.26 \\
\text { ntinued) }\end{array}$ \\
\hline
\end{tabular}


Table 2: (Continued)

\begin{tabular}{|c|c|c|c|c|}
\hline Variable & Category & Description & $n$ & $\%$ \\
\hline \multirow{3}{*}{ Frequency } & Low & Less than 12 times per year & 61 & 43.26 \\
\hline & High & More than 50 times per year & 58 & 41.13 \\
\hline & Medium & $\begin{array}{l}\text { From } 12 \text { to } 50 \text { times per year (more than } \\
\text { once a week in summer months) }\end{array}$ & 22 & 15.60 \\
\hline \multirow{6}{*}{$\begin{array}{l}\text { Positive } \\
\text { elements }\end{array}$} & Landscape & Elements of landscape are stated & 42 & 29.79 \\
\hline & $\begin{array}{l}\text { Degree of } \\
\text { Naturalness }\end{array}$ & $\begin{array}{l}\text { Stated element is degree of naturalness or } \\
\text { absence of human elements }\end{array}$ & 41 & 29.08 \\
\hline & $\begin{array}{l}\text { Particular } \\
\text { elements }\end{array}$ & $\begin{array}{l}\text { Some element like dunes, wildlife or crops } \\
\text { are stated }\end{array}$ & 28 & 19.86 \\
\hline & Atmosphere & It unites answers related to tranquillity & 22 & 15.60 \\
\hline & Equipment & Any equipment is stated as positive & 6 & 4.26 \\
\hline & Blank & No element is stated & 2 & 1.42 \\
\hline \multirow{6}{*}{$\begin{array}{l}\text { Negative } \\
\text { elements }\end{array}$} & Bad management & $\begin{array}{l}\text { All issues that are caused by bad manage- } \\
\text { ment of wetlands (dirty, uncared for, equip- } \\
\text { ment in bad condition and so on) }\end{array}$ & 51 & 36.17 \\
\hline & Blank & No element is stated & 39 & 27.66 \\
\hline & Visual impact & $\begin{array}{l}\text { Answers related to landscape quality or } \\
\text { visual impact }\end{array}$ & 23 & 16.31 \\
\hline & Human presence & $\begin{array}{l}\text { Answers related to overcrowding, traffic or } \\
\text { noise }\end{array}$ & 15 & 10.64 \\
\hline & $\begin{array}{l}\text { Unpleasant } \\
\text { wildlife }\end{array}$ & Essentially mosquitos and gulls & 9 & 6.38 \\
\hline & External factors & Independent elements such as climate & 4 & 2.84 \\
\hline
\end{tabular}

An evaluation of the wetlands on a five-point scale achieved an average score of 4.21, a standard deviation of 0.92 and a mode of 5 . Hence, data showed a strong negative skewness $(-1.49)$, with an abundance of high values. As previously mentioned, because that variable did not show a normal distribution ( $\mathrm{p}<0.001$ in Kolmogorov-Smirnov test), a KruskalWallis test was used to test relationships with factors. Five variables showed significant relationships $(\mathrm{p}<0.1)$ with an evaluation of the wetlands: time, typology, motivation, positive elements and negative elements (Table 3). Afternoon visitors awarded the highest points (4.43), while visitors in the morning gave the lowest (4.03). Excursionists were the typology that gave the worst evaluation (3.93), while national tourists and foreign second home owners gave better evaluations $(4.55,4.54)$. As for motivation for visiting, the highest points were awarded by those visitors looking for tranquillity or with aesthetic motivation (4.83, 4.43), while the worst scores were given by visitors with no motivation for visiting the wetland (3.93). Positive elements linked to high scores were particular elements like wildlife or dunes (4.55), while low points were linked to equipment aspects mentioned as positive (3.83). Finally, visitors who stated negative elements related to bad management also awarded the lowest scores and visitors who stated no negative elements or stated unpleasant wildlife gave the highest points (4.67 both). 
Table 3: Significant relationships $(\mathrm{p}<0.1)$ with evaluation of wetlands.

\begin{tabular}{|c|c|c|c|c|}
\hline Variable & Category & Mean & SD & $\mathbf{n}$ \\
\hline \multirow{3}{*}{ Time $(\mathrm{p}=0.074)$} & Afternoon & 4.433333 & 0.7448505 & 60 \\
\hline & Noon & 4.30000 & 0.6749486 & 10 \\
\hline & Morning & 4.028169 & 1.0552160 & 71 \\
\hline \multirow{6}{*}{$\begin{array}{l}\text { Typology }(\mathrm{p}= \\
0.066)\end{array}$} & National tourist & 4.546875 & 0.6138111 & 32 \\
\hline & Foreign second home & 4.535714 & 0.6344072 & 14 \\
\hline & National second home & 4.209677 & 1.1088597 & 31 \\
\hline & Local & 4.100000 & 1.0711528 & 20 \\
\hline & Foreign tourist & 4.058824 & 0.6586528 & 17 \\
\hline & Excursionist & 3.925926 & 1.0715168 & 27 \\
\hline \multirow{4}{*}{$\begin{array}{l}\text { Motivation }(\mathrm{p}= \\
0.090)\end{array}$} & Tranquillity & 4.833333 & 0.4082483 & 6 \\
\hline & Aesthetic & 4.434783 & 0.7877521 & 23 \\
\hline & Recreational & 4.297101 & 0.7241569 & 69 \\
\hline & Without motivation & 3.930233 & 1.2227087 & 43 \\
\hline \multirow{6}{*}{$\begin{array}{l}\text { Positive elements } \\
(p=0.079)\end{array}$} & Particular elements & 4.553571 & 0.5666550 & 28 \\
\hline & Blank & 4.500000 & 0.7071068 & 2 \\
\hline & Landscape & 4.345238 & 0.8445528 & 42 \\
\hline & Atmosphere & 4.340909 & 0.8364660 & 22 \\
\hline & Degree of naturalness & 3.878049 & 1.0769197 & 41 \\
\hline & Equipment & 3.833333 & 1.4719601 & 6 \\
\hline \multirow{6}{*}{$\begin{array}{l}\text { Negative elements } \\
(p=0.002)\end{array}$} & Blank & 4.666667 & 0.4635863 & 39 \\
\hline & Unpleasant wildlife & 4.666667 & 0.5000000 & 9 \\
\hline & External factors & 4.250000 & 0.5000000 & 4 \\
\hline & Visual impact & 4.173913 & 1.0292174 & 23 \\
\hline & Human presence & 4.133333 & 0.5163978 & 15 \\
\hline & Bad management & 3.872549 & 1.1525760 & 51 \\
\hline
\end{tabular}

\section{DISCUSSION}

Firstly, elements which influence the evaluation of the wetlands are of interest. Despite most visitors giving a positive evaluation, there were relevant differences linked to motivations for visiting the wetland. Those are coherent with other studies that showed how the uses of ecosystem services determined the behaviour of visitors regarding the site [23] or with studies that found that more passive activities were linked to better environmental behaviour [19]. It is also significant that sociodemographic variables were not linked to evaluation of wetlands, contrary to several previous studies that showed age and sex were determinant characteristics $[19,31]$. Visitor typology also influenced the awarded scores, conditioned by the relationship between typology and motivation. For instance, the excursionist group gave the lowest points and, at the same time, stated having no motivation for visiting the wetland because they use it as a car park to access the beach.

Regarding motivation of visitors, it stands out that most uses were recreational. Uses like running or cycling were more numerous than walking. Recreational uses were more frequent 
in local inhabitants, as shown by Birol et al. [2]. Usage detected by direct observation coincided largely with that detected in similar studies [5, 32]. Consumptive uses like hunting, fishing or harvesting were not detected, as Smardon [6] showed for wetlands in industrialized countries. There was a similarity between visitors who stated recreational activities $(16.31 \%)$ and the number of visitors who walked $(11.88 \%)$. Hence, it can be deduced that visitors who visited the site for running or cycling prioritized recreational use rather than aesthetic, undervaluing the environmental and heritage worth of seaside wetlands [33]. Furthermore, it cannot be obviated that almost a third of visitors only used the wetlands as a car park, as we mentioned above.

Although recreational uses were dominant, when we asked about positive elements of wetlands, visitors mentioned elements related to aesthetic values. Answers linked to landscape, or degree of naturalness or particular elements like wildlife, rice crops or dunes represented $78.73 \%$ of visitors. Proportions were similar to other seaside wetlands, for instance, in S'Albufera (Mallorca, Spain), where $72 \%$ of uses were related to nature watching [18]. The Millennium Ecosystem Assessment [1] also showed that tourism displayed a growing regard among visitors for biological diversity and abundance. Lee [17] concluded that tourists visited wetlands for their natural resources rather than for any other touristic attraction. Despite wildlife being present as a positive element (10.41\% of answers), other more generic elements like landscape or degree of naturalness were more frequently mentioned. This is in contrast to other wetlands, where wildlife was stated as the main attraction for visitors [10]. Despite the prominence of recreational uses, only $4.26 \%$ of visitors stated positive elements linked to equipment, contrasting with Carlsson et al. [31], who found that landscape and nature shared importance with equipment. According to Palmer and Smardon [5], no visitor stated the elements linked to other ecosystem services like protection against weather events or provision functions, contrary to studies in other regions [2, 4, 34].

Visitors to seaside wetlands used to be critical regarding the management of wetlands; negative comments like 'dirty', 'uncared for', 'equipment in bad condition' were very common $(36.17 \%)$. To these responses, answers linked to visual impact could be added, because all of them referred to human elements such as power lines or built-up areas. Although there were problems of eutrophication in two selected areas, a problem that reduced the aesthetic and recreational values of wetlands [1], no visitors mentioned this. Hence, eutrophication was not a perceived problem in studied wetlands, perhaps because waterbodies represented little importance in the whole wetlands, only three visitors mentioned waterbodies as a positive element.

\section{CONCLUSION}

In this communication we presented the recreational usage of visitors to seaside wetlands and the perceptions and motivations of visitors. Despite most usage and motivation for visiting wetlands being recreational, we showed that visitors mentioned the landscape and nature as positive elements. We also analysed those elements which influenced the scores that visitors gave to wetlands. Aspects like motivation or typology of visitor were determinant rather than sociodemographic characteristics.

We discovered that wildlife and waterbodies had little importance in the preferences and motivation of visitors, contrasting with other wetlands, where wildlife and water were the main attraction for visitors. This suggested that touristic management could promote those aspects of wetlands, attracting activities related to wildlife, such as birdwatching, very common in most wetlands. On the other hand, waterbodies could become an important attraction 
in analysed wetlands if problems like eutrophication were solved because water is always an attraction for nature-based tourism and the analysed wetlands had a big enough body of water.

Hence, tourism can become a conservation actor in seaside wetlands, because the elements appreciated by tourism are coherent with a healthy ecosystem. Improving landscape quality, degree of naturalness and wildlife habitats are conservation measures and, at the same time, they improve wetlands as a touristic attraction. They should, however, coexist with recreational equipment for enjoying wetlands because, if tourists and local inhabitants are not able to enjoy the natural areas, they will not agree with conservation policies.

In future research, it could be interesting to analyse the willingness-to-pay of visitors because Spain is still recovering from the financial crisis and conservation costs have to be borne by some party. A tourist tax or a fee might, for instance, help to secure funding for conservation. But, could it apply a break to the number of visitors to tourism destinations and to wetlands?

\section{REFERENCES}

[1] Millennium Ecosystem Assessment, Ecosystem Services and Human Well-Being: Wetlands and Water Synthesis, 2005.

[2] Birol, E., Hanley, N., Koundouri, P. \& Kountouris, Y., Optimal management of wetlands: quantifying trade-offs between flood risks, recreation, and biodiversity conservation. Water Resources Research, 45(11), pp. 1-11, 2009. http://dx.doi.org/10.1029/2008WR006955

[3] Kim, S.O. \& Shelby, B., Effects of information on perceived crowding and encounter norms. Environment Management, 47, pp. 876-884, 2011. http://dx.doi.org/10.1007/s00267-011-9654-z

[4] Smardon, R.C., A review of wetland use and management of the Nariva Swamp, Trinidad. Caribbean Geography, 17(1 \& 2), pp. 73-93, 2012.

[5] Palmer, J.F. \& Smardon, R.C., Human-use values of wetlands; an assessment in Juneau, Alaska. Proceedings of the National Wetland Symposium: Urban Wetlands, eds. J.A. Kusler, S. Daly \& G. Brooks, Association of Wetland Managers: Berne, NY, pp. 108114, 1988.

[6] Smardon, R.C., Heritage values and functions of wetlands in Southern Mexico. Landscape and Urban Planning, 74(3-4), pp. 296-312, 2006.

http://dx.doi.org/10.1016/j.landurbplan.2004.09.009

[7] Ghermandi, A. \& Nunes, P.A.L.D., A global map of costal recreation values: results from a spatially explicit based meta-analysis. Ecological Economics, 86, pp. 1-15, 2013. http://dx.doi.org/10.1016/j.ecolecon.2012.11.006

[8] Zhao, Q., Bai, J., Huang, L., Gu, B., Lu, Q. \& Gao, Z., A review of methodologies and success indicators for coastal wetland restoration. Ecology Indicator, 60, pp. 442-452, 2016. http://dx.doi.org/10.1016/j.ecolind.2015.07.003

[9] Patrick, W.H.J. (ed.), Wetlands: Their Use and Regulation, U.S. Congress, Office of Technology Assessment: Washington D.C., 1984.

[10] Nassauer, J.I., Monitoring the success of metropolitan wetland restorations: cultural sustainability and ecological function. Wetlands, 24(4), pp. 756-765, 2004. http://dx.doi.org/10.1672/0277-5212(2004)024[0756:MTSOMW]2.0.CO;2 
[11] Mahan, B.L., Polasky, S. \& Adams, R.M., Valuing urban wetlands: a property price approach. Land Economics, 76(1), pp. 100-113, 2000.

http://dx.doi.org/10.2307/3147260

[12] Manuel, P.M., Cultural perceptions of small urban wetlands: cases from the halifax regional municipality, Nova Scotia, Canada. Wetlands, 23(4), pp. 921-940, 2003. http://dx.doi.org/10.1672/0277-5212(2003)023[0921:CPOSUW]2.0.CO;2

[13] Dhakal, S.P., An exploratory perspective on sustainable tourism as wise-use of a protected wetland in Thailand. International Journal of Tourism Policy, 5(3), pp. 159-172, 2014. http://dx.doi.org/10.1504/IJTP.2014.063079

[14] “Ecotourism Australia." [Online], available at http://www.ecotourism.org.au/.

[15] "Lake District National Park." [Online], available at http://www.lakedistrict.gov.uk/.

[16] Barbier, E.B., Acreman, M. \& Knowler, D., Economic Valuation of Wetlands: A Guide for Policy Makers and Planners, RAMSAR Convention Bureau: Gland, 1997.

[17] Lee, T.H., How recreation involvement, place attachment and conservation commitment affect environmentally responsible behavior. Journal of Sustainable Tourism, 19(7), pp. 895-915, 2011.

http://dx.doi.org/10.1080/09669582.2011.570345

[18] Faccioli, M., Riera Font, A. \& Torres Figuerola, C.M., Valuing the recreational benefits of wetland adaptation to climate change: a trade-off between species' abundance and diversity. Environment Management, 55(3), pp. 550-563, 2014. http://dx.doi.org/10.1007/s00267-014-0407-7

[19] Luo, Y. \& Deng, J., The new environmental paradigm and nature-based tourism motivation. Journal Travel Resarach, 46(4), pp. 392-402, 2007. http://dx.doi.org/10.1177/0047287507308331

[20] Barbaza, Y. \& Cals i Güell, J., El Paisatge humà de la Costa Brava, Edicions: Barcelona 62, 1988.

[21] Essex, S., Kent, M. \& Newnham, R., Tourism development in mallorca: is water supply a constraint? Journal of Sustainable Tourism, 12(1), pp. 4-28, 2004. http://dx.doi.org/10.1080/09669580408667222

[22] Sardà, R., Mora, J., Ariza, E., Avila, C. \& Jimenez, J.A., Decadal shifts in beach user sand availability on the Costa Brava (Northwestern Mediterranean Coast). Tourism Management, 30(2), pp. 158-168, 2009. http://dx.doi.org/10.1016/j.tourman.2008.05.011

[23] Asah, S.T., Guerry, A.D., Blahna, D.J. \& Lawler, J.J., Perception, acquisition and use of ecosystem services: human behavior, and ecosystem management and policy implications. Ecosystem Services, 10, pp. 180-186, 2014. http://dx.doi.org/10.1016/j.ecoser.2014.08.003

[24] Milcu, A.I., Hanspach, J., Abson, D. \& Fischer, J., Cultural ecosystem services: a literature review and prospects for future research. Ecology Social, 18(3), p. 44, 2013. http://dx.doi.org/10.5751/ES-05790-180344

[25] Benages-Albert, M., Di Masso, A., Porcel, S., Pol, E. \& Vall-Casas, P., Revisiting the appropriation of space in metropolitan river corridors. Journal of Environment Psychology, 42, pp. 1-15, 2015.

http://dx.doi.org/10.1016/j.jenvp.2015.01.002

[26] Freeman, A.M., The Measurement of Environmental and Resource Values: Theory and Methods, Resources for the Future: Washington, D.C., 2003. 
[27] Martí, C. \& Fraguell, R.M., La Costa Brava, Fundació Caixa Girona: Girona, 2007.

[28] Cazorla, X. (ed.), Pla de foment del turisme de natural als espais naturals protegits de Catalunya, Generalitat de Catalunya: Barcelona, 2015.

[29] Saldaña, J., The Coding Manual for Qualitative Researchers, SAGE: London, 2013.

[30] Kruskal, W.H. \& Wallis, W.A., Use of ranks in one-criterion variance analysis. Journal of the American Statistical Association, 47(260), pp. 583-621, 1952. http://dx.doi.org/10.1080/01621459.1952.10483441

[31] Carlsson, F., Frykblom, P. \& Liljenstolpe, C., Valuing wetland attributes: an application of choice experiments. Ecology Economics, 47(1), pp. 95-103, 2003. http://dx.doi.org/10.1016/j.ecolecon.2002.09.003

[32] Smardon, R.C., Aesthetic, recreational, landscape values of urban wetlands. Proceedings of the National Wetland Symposium: Urban Wetlands, eds. J.A. Kusler, S. Dally \& G. Brooks, Association of Wetland managers: Oakland, California, 1988, pp. 92-96.

[33] Blázquez Salom, M., Los usos recreativos y turísticos de los espacios naturales protegidos. el alcance del ocio en el medio natural de Mallorca. Investig. Geográficas, 19, pp. 105-126, 1998.

http://dx.doi.org/10.14198/INGEO1998.19.02

[34] Kim, T. \& Petrolia, D.R., Public perceptions of wetland restoration benefits in Louisiana. ICES Journal Marine Science, 70(5), pp. 1045-1054, 2013. http://dx.doi.org/10.1093/icesjms/fst026 